\title{
Customers' satisfaction in public and private sector banks in India: A comparative study.
}

\author{
Anis Ali ${ }^{*}$, L.S. Bisht ${ }^{2}$ \\ ${ }^{1}$ CBAK, Prince Sattam Bin Abdulaziz University, KSA, Saudi Arabia \\ ${ }^{2}$ Commerce Department, DSB Campus, Kumaun University, Nainital (UK), India
}

\begin{abstract}
Banking is to be considered as pure financial service industry and responsible for the economic development of an economy upto great extent. Satisfaction of customers is the vital for retaining existing customers and attracting prospective customers to widen the level of operational activities in any concern. In India, Private and Public banks are rendering financial services. The Policies and Strategies of Private and Public banks are different that leads variation in the customers' satisfaction level. This paper tries to measure satisfaction level of customers of Public and Private Banks and factors responsible for variation in customers' satisfaction between Private and Public banks in India. The objective of the research is to get the satisfaction level, variations in satisfaction level and reasons responsible for variations in satisfaction level or dissatisfaction in public and private banks. This research is based on primary informations obtained from customers of Public and Private sectors banks in India. Overall, Customers of Private and Public sector banks are satisfied except some tangibles and behavioral factors of the banks employees due to the policies, strategies for tangibles and inefficiency of the employees. So, there are need to consider tangibles and behavioral factors of the employees to enhance the level of satisfaction in Public banks.
\end{abstract}

Keywords: Customers' satisfaction, Banking services, Private \& public banks, Expectations \& perceptions, SERVQUAL.

Accepted on October 21, 2018

\section{Introduction}

The satisfaction of the customers is very important factor in all service industries to enhance and improve the profitability and financial performance of the concern. Banking sector is purely financial service industry and the customer's satisfaction is much more important to run banking business successfully. The satisfaction level of the customers is varying due to different kinds of banking services and their benefit to the customers. There are so many factors that are responsible in the discrimination of the services for different types of banking customers and lead to uneven satisfaction level. In India, Private and Public sector banks are providing the financial services to the different types of customers in rural and urban areas. The offices of the Private and Public sector banks are increasing rapidly (Table 1).

From the above details $[1,2]$, it is obvious that the numbers of offices of Public sector are five times more than the Private sector bank offices. But, the compound annual growth rates (CAGR) of Private sector Banks are higher than two times of Public sector banks offices. This absolute and relative growth of Public and Private sector banks directing towards enhancement of customers' satisfaction level to retain existing and attract new customers. As Puja K and Yukti A reveals that Private Banks have more satisfied customers due to good services and retaining its customers by offering better facilities comparatively public sector banks. Mishra S and Patra SK revealed that service quality, customers' satisfaction and customers' retentions are the major challenges in banking sector. However, Public sectors' Banks have to improve in the area of dealing with the customers and Private sectors' Banks need to focus upon their loans and insurance services. Public sectors banks need to improve their infrastructural facilities and provide some training to the employees' who are dealing with customers. In Banks, branches equipped with latest technology, developed infrastructure and well trained employees, convenient office hours and locations of the branches are the factors affecting the customers' satisfaction level. The responsiveness and empathy of the staff of rural branches are required some changes and improvement to

Table 1: Growth of public sector and private sector banks in India-Bank office wise.

\begin{tabular}{|c|c|c|c|c|c|c|c|c|c|}
\hline Bank offices- Group wise & 2005-06 & 2006-07 & 2007-08 & 2008-09 & $2009-10$ & $2010-11$ & 2011-12 & $2012-13$ & CAGR (\%) \\
\hline Public Sector & 50168 & 52104 & 55080 & 57979 & 62080 & 65800 & 70969 & 75779 & 5.29 \\
\hline Private Sector & 6835 & 7427 & 8322 & 9288 & 10516 & 12097 & 13970 & 16001 & 11.22 \\
\hline
\end{tabular}

Source: Malyadri P, Sirisha S (2015) An analytical study on trends and progress of Indian banking industry. 
satisfy the customers [1]. Satisfaction is very necessary in the banking industry to provide better financial services to enhance the level of profitability and strengthen the financial position. Private sector banks' offices growth is evident that the service quality and customers' satisfaction are the prime consideration for the development of the banking business in India. Public sector banks are more capable to attract and retain customers due to their reputation and convenient location of bank branches in India. There is need to get opinion of customers about service quality and customers' satisfaction in banks and identify the areas where improvements are necessary to make customers more satisfied.

\section{Literature Review}

Puja K and Yukti A reveals that Private Banks have more satisfied customers due to good services. Private sector banks are successfully maintaining level of quantity of its customers by providing better banking services than Public sector Banks. In any economy, innovative technologies and changing expectations of markets, consideration of quality of each and every service is important to enhance customers' satisfaction level. Further, Puja K and Yukti A advocated that success mantra could be customer centric orientation, where the customer relationships management with its customers in Private sector Banks has been successful in achieving its goals. However, Public sector banks have to improve in the area of dealing with the customers. Private Banks need to focus on their loan and insurance services while Public sectors banks need to improve their infrastructural facilities and provide some training to the employees' who are dealing with customers. Equipped with latest technology, developed infrastructure and well trained employees, convenient office hours and locations of the branches are the factors affecting the customers' satisfaction level. Mishra US, Sahoo KK, Mishra S and Patra SK (2010) explained that service quality, customers satisfaction, customers retention, customers loyalty etc. are the major challenges to in attracting and retaining customers in banking sector. Among all, customers' satisfaction is playing a significant role in attracting, retaining customers and creating brand loyalty among the customers. Mishra US, Mishra BB, Praharaj S, and Mahapatra R observed that whole banking sector is facing the challenge of attracting and retaining customers. They revealed that public sector banks are better than private sector banks in attracting and retaining customers. The main factors for opening a new account are convenient location and reputation of the banks etc. Retired or higher age group business man customers prefer public sector banks due to its high reputation. The customers of public sectors banks are more satisfied than private sector banks. But, the major factors of dissatisfaction of customers in public sector banks are enquiry counter and front office services. The private sector banks are executing pure banking services while public sector banks have to deploy some social responsibilities. Nirmaljeet $\mathrm{V}$ and Prabhjot KM explains that infrastructural facilities in the branch not only leads to customer satisfaction but overall improves the working of the branch [3] revealed that the Private Banks has advanced technologically but the reverse situation is available in Public sector banks observed from their analysis that that customer satisfaction in banks vary according to the quality of services. Nominal charges of services, location of bank branches and staff attitude towards solving problems of customers are the factors responsible for highest customer's satisfaction. Private bank customers are more satisfied with their bank because of their multiple branches at convenient locations and technological facilities. Public sector banks are not so technologically advanced. But, Public sector banks are maintaining satisfaction level of the customers due to its reliability, high reputation in the society and low charges of the services. Customer care services of the Private Banks are better than Public sector banks. Vijay PG and Agarwal PK found in their research that the empathy, friendly attitude of staff, and customer guidance, customer support are the behavioral treatment factors for high customers' satisfaction. Tangibility and empathy are the other factors create satisfaction among customers. Private and Public sectors banks are needed to consider the weak areas of the concern to enhance the level of satisfaction. According to Doddaraju ME, the behavior of Public sector banks employees are not so courteous comparatively Private sector banks. The Public banks should provide special training and developmental programs to the employees engaged in directly dealing with customers. Development of infrastructure and tangibility of the banks are also affecting the satisfaction level of the customers. The new schemes of the investment and other related informations should be published and displayed systematically. Customer relation management and promotional schemes of the banks also increase satisfaction level. Puri J, Yadav SP found that the public sectors bank performed better than private sector banks in all dimensions and revealed that the new private sector banks are performing better than the old private sector banks. The technical efficiency was better in public sector banks comparatively private sector banks [4] indicated that the time factor is very important for the customers and customer relationship should be maintained to satisfy the customers. Location of the bank, timely delivery of the services and customer oriented policy making are the factors enhance satisfaction in Private sector banks resulting larger customers base. Public sector banks are equipped with latest technology and technically trained staff. The infrastructural appearances and extra services like home facility, round the clock facility etc. and query resolution through telephone, lowest prices of the services and above all availability of the multiple products are the special features in Private Banks to enhance the level of satisfaction of the customers [2] observed that there is a significant relation between customer satisfaction and dimensions of service quality in Public sector commercial Banks. Khushboo B, Naveena C and Neha J explained in their study that people are more satisfied from the Private sector banks due to their better services provided by them in terms of fast transactions, fully automatic computerized facilities, more and convenient working hours, advisory services, skilled and co-operative staff, better customer relationship management etc. But, there is need to make aware rural customers about the services of Private 
Banks. The most facility availed by customers of the Public sector banks are ATM and least facilities are demat a/c and foreign transfer of funds. The Private sector banks' customers are using internet or phone banking by ATM/ Debit card. Justin P, Arun M and Garima S [5] explains about Private sector banks' fast services, quick connection to the right person, efforts to reduce time in processing transactions, knowledge of the banks products and responsiveness of the employees are positively associated with the customers' satisfaction level. In Public sector banks, slow services, low knowledge of banking products appearance is the factors negative for the satisfaction level of the customers. Kesari S and Nitin G [6,7] explain in his studies that Public sector banks should work to attain the confidence of salaried class, lower age group customers, students and self-employed businessman people. Private sector banks should give much attention to the lower income group customers also because the higher income group found the services provided by banks to be more effective but high service charges, which is out of the reach of the lower income group of customers. Seema S stated that the performance of urban banks on service delivery and customer satisfaction exceeds the expectations of the customers in terms of physical facilities, appearance of employees and attitude of employees to help customers. Kumar J, Thamilselvan R [8-13] stated in his research that private sector banks are competing with the public sector banks in terms of Capital Adequacy, Asset Quality, Management Efficiency, Earning Capacity and Asset Quality. They found that capital adequacy, assets quality and liquidity in public sector banks while management efficiency, earning quality banks was better, comparatively [1]. found that few customers are dissatisfied because of the poor responsiveness and empathy of the employees in urban and rural area branches. Further, concluded that there is need to give special training to the employees who are working in rural areas directly dealing with the customers. Equipment of branches with latest technology, Publication of required informations on the websites of the bank and unbiased behavior of the employees are the factors lead to customers' satisfaction in banking industry.

\section{Research Problems}

Banking sector in any nation is the vital for developing the business and economy. Banks are the heart of the business sector of any economy and supply the necessary money blood to all business organizations and simultaneously support the weaker sectors or the organizations of a nation. Customers' satisfaction is the elemental factor that decides the success of any bank. Now a days, Private and Public sector banks are expanding their branches in urban as well as in rural areas to get more and more customers. Brach size, services, infrastructure, facilities, staff, working hours etc. is varying according to the governing ownership and location the branch i.e. Private sector and Public sector or Rural and Urban branch. So, there is need to assess the satisfaction level of customers from Private and Public sector Banks or Rural and Urban areas to provide the suggestions for the improvement of services and other tangibles of the banks.

\section{Research Objectives}

The objectives of the research are as follows:

- To know the satisfaction level of customers from Private and Public sector banks.

- To know the difference between the satisfaction level of Private and Public sector customers of banks considering various aspects of satisfaction.

- To know the factors responsible for the low satisfaction level among the banking customers.

- To provide suggestions to improve satisfaction level of the customers.

\section{Research Methodology}

This research is purely based upon the primary informations obtained from the banking customers of different parts of India. There were 200 banking customers, who responded well the all informations containing in the questionnaire. Persuraman et al. [14] supports and applied five factors questionnaire to know the satisfaction level in service sector. The questionnaire contains five factors as per the SERVQUAL of Persuraman et al. [14]. There were 51 questions in the SERVQUAL questionnaire to get the differences in satisfaction levels of customers of Public sector and Private sector banks in various terms (Demographical -11 questions, Expectations -20 questions, Perceptions-20 questions). The respondents were from different parts of India, but mostly from Uttar Pradesh due to native state of the researcher. The mean difference between expectations and perceptions of the customers calculated to know the satisfaction level differences. The demographical analysis is made to know the satisfaction level differences of customers of Private and Public sector assuming the various demographical factors as base. Chi Square is used to test hypotheses to get the differences between or among the dimensions of customers' satisfaction and Private Banks, Public Banks and in between related terms. The secondary informations are obtained from the other sources like research papers, published papers etc.

\section{Hypothesis of the Study}

The Null and Alternative hypotheses of the study are as follows:

1. $\mathrm{H}_{0}$ : There is no significant difference between being satisfied and not satisfied customers from their rural and urban branches.

H1: There is a significant difference between being satisfied and not satisfied customers from their rural and urban branches.

2. $\mathrm{H}_{0}$ : There is no significant difference between satisfaction and not satisfaction in terms of being employment of the customers.

$\mathrm{H}_{1}$ : There is a significant difference between satisfaction and not satisfaction in terms of being employment of the customers. 
3. $\mathrm{H}_{0:}$ There is no significant difference between Public and Private Banks in terms of gender of the customer.

$\mathrm{H}_{1}$ : There is a significant difference between Public and Private Banks in terms of gender of the customer.

4. $\mathrm{H}_{0}$ : There is no significant difference between Public and Private Banks in terms of income of the customer.

$\mathrm{H}_{1}$ : There is a significant difference between Public and Private Banks in terms of income of the customer.

5. $\mathrm{H}_{0}$ : There is no significant difference between being satisfied and not satisfied customers from their Public and Private sector banks.

$\mathrm{H}_{1}$ : There is a significant difference between being satisfied or not satisfied customers from their Public and Private Banks.

6. $\mathrm{H}_{0}$ : There is no significant difference between Public and Private Banks in terms of being types of banks account.

$\mathrm{H}_{1}$ : There is significant difference between Public and Private banks in terms of being types of banks account.

7. $\mathrm{H}_{0}$ : There is no significant difference between being satisfied and unsatisfied in terms of male and female.

$\mathrm{H}_{1}$ : There is significant difference between being satisfied and unsatisfied in terms of male and female.

8. $\mathrm{H}_{0}$ : There is no significant difference in perception and expectation of customers from urban and rural branch in terms of Tangibles, Reliability, Responsiveness, Assurance and Empathy.

$\mathrm{H}_{1}$ : There is significant difference in perception and expectation of customers from urban and rural branch in terms of Tangibles, Reliability, Responsiveness, Assurance and Empathy.

9. $\mathrm{H}_{0}$ : There is no significant difference in perception and expectation of customers from Private, Public and Public and Private Banks in terms of Tangibles, Reliability, Responsiveness, Assurance and Empathy.

10. $\mathrm{H}_{1}$ : There is significant difference in perception and expectation of customers from Private, Public and Public and Private banks in terms of Tangibles, Reliability, Responsiveness, Assurance and Empathy.

\section{Limitations of the Study}

The respondents are only from few parts of India and rural respondents are very less comparatively urban. Some respondents filled the questionnaire unwillingly. The informations are collected from the respondents within one month and study is static in nature while the satisfaction of the customers varying according to the change in the services quality of the banks. So, the results of study may be different due to lag in information collection, analysis and finally publication of research article.

\section{Data Interpretation and Analysis}

Analysis of SERVQUAL reveals that customers from rural branches are more satisfied in terms of Tangibles, Reliability and Empathy while urban customers are more satisfied in terms of responsiveness and Assurance. SERVQUAL analysis on the basis of Public and Private Banks indicating that Private sector customers are more satisfied in all dimensions of services even gap between perception and expectation is negative in case of assurance of Public banks. Hence, the customers of Public sector banks comparatively less satisfied with the interrupted services of ATMs in rural and remote areas and even they are not assured about the charging service charges and courteous services of the banks' staff. The ATMs of Public sector banks are always crowded and not located at convenient places to reach customers (Tables 2 and 3).

\section{Hypothesis 1}

The value of chi Square is 2.56 lesser than the critical value $(3.841)$ at $5 \%$ level of significance $($ d.f. $=1)$ to get the difference in levels of customers satisfaction in terms of rural and urban branches. So, $\mathrm{H}_{0}$ of Hypothesis $\mathrm{I}$ is accepted and there is no significant difference between the customers of Urban and rural branches (Appendix 1).

\section{Hypothesis 2}

The value of Chi Square is 42.35 more than the critical value $(7.82)$ at $5 \%$ level of significance $($ d.f. $=3)$ to get the

Table 2: SERVQUAL gap between satisfaction level of urban and rural customers.

\begin{tabular}{|c|c|c|c|c|c|}
\hline \multicolumn{6}{|c|}{ Expectation } \\
\hline & Tangibles & Reliability & Responsiveness & Assurance & Empathy \\
\hline Rural & 1.57 & 1.83 & 2.02 & 2.09 & 1.93 \\
\hline Urban & 1.5 & 1.67 & 1.74 & 1.82 & 1.81 \\
\hline \multicolumn{6}{|c|}{ Perception } \\
\hline & Tangibles & Reliability & Responsiveness & Assurance & Empathy \\
\hline Urban & 1.76 & 2.2 & 2.09 & 2.06 & 2.32 \\
\hline \multicolumn{6}{|c|}{ GAP (P-E) } \\
\hline & Tangibles & Reliability & Responsiveness & Assurance & Empathy \\
\hline Rural & 0.28 & 0.63 & 0.32 & 0.16 & 0.64 \\
\hline Urban & 0.26 & 0.53 & 0.35 & 0.24 & 0.51 \\
\hline
\end{tabular}


Table 3: SERVQUAL gap between satisfaction level of public, private and public private customers.

\begin{tabular}{|c|c|c|c|c|c|}
\hline \multicolumn{6}{|c|}{ Expectation } \\
\hline & Tangibles & Reliability & Responsiveness & Assurance & Empathy \\
\hline Public & 1.55 & 1.66 & 1.81 & 2.02 & 1.93 \\
\hline Private & 1.5 & 1.72 & 1.75 & 1.75 & 1.79 \\
\hline Public \& Private & 1.48 & 1.7 & 1.8 & 1.85 & 1.77 \\
\hline \multicolumn{6}{|c|}{ Perception } \\
\hline Public & 1.72 & 2.07 & 1.93 & 1.94 & 2.14 \\
\hline Private & 1.86 & 2.45 & 2.29 & 2.19 & 2.43 \\
\hline Public \& Private & 1.67 & 2.02 & 2.05 & 2.08 & 2.47 \\
\hline \multicolumn{6}{|c|}{ GAP (P-E) } \\
\hline & Tangibles & Reliability & Responsiveness & Assurance & Empathy \\
\hline Public & 0.16 & 0.41 & 0.12 & -0.08 & 0.22 \\
\hline $\mathrm{p} / \mathrm{p}$ & 0.19 & 0.32 & 0.25 & 0.23 & 0.71 \\
\hline
\end{tabular}

differences in satisfaction levels of customers in terms of the employment. So, $\mathrm{H}_{0}$ is rejected and there is significant difference among the customers in terms of their employment or jobs (Appendix 2).

\section{Hypothesis 3}

The value of Chi Square is 25.79 more than the critical value $(5.99)$ at $5 \%$ level of significance $($ d.f. $=2)$ to get the differences of Public, Private, Public and Private banks in terms gender of customer. So, $\mathrm{H}_{0}$ is rejected and there is significant difference among the Public, Private, Public and Private Banks in terms of gender of customer (Appendix 3).

\section{Hypothesis 4}

The value of chi Square is 1.097 lesser than the critical value $(12.592)$ at $5 \%$ level of significance $($ d.f. $=6)$ to get the differences in Public and Private banks in terms of income groups of customers. So, $\mathrm{H}_{0}$ of Hypothesis IV is accepted and there is no significant difference between the customer satisfaction according to their income group (Appendix 4).

\section{Hypothesis 5}

The value of chi Square is 8.797 more than the critical value $(5.991)$ at $5 \%$ level of significance $($ d.f. $=2)$ to get the differences in satisfaction levels of customers of Public and Private banks. So, $\mathrm{H}_{0}$ of Hypothesis $\mathrm{V}$ is rejected and there is significant difference between the Public, Private, Public \& Private customers of banks (Appendix 5).

\section{Hypothesis 6}

The calculated value of chi Square is .1912 lesser than the critical value (12.59) at 5\% level of significance (d.f. $=6)$ to get the differences in Public and Private banks in terms of types of their bank accounts. So, $\mathrm{H}_{0}$ of Hypothesis VI is accepted and there is no significant difference in Public and Private Banks in terms of types of their bank accounts (Appendix 6).

\section{Hypothesis 7}

The value of chi Square is 1.713 lesser than the critical value $(3.841)$ at $5 \%$ level of significance $($ d.f. $=1)$ to get the difference in satisfaction level of customers' in terms of their gender i.e male or female. So, $\mathrm{H}_{0}$ of Hypothesis VII is accepted and there is no significant difference in satisfaction level of customers in terms of male and female (Appendix 7).

\section{Hypothesis 8}

The value of SERVQUAL dimensions of chi Square is 0.00265 lesser than the critical value (11.143) at 5\% level of significance (d.f. $=4)$ to get difference in perception and expectation of customers from urban and rural branch in terms of Tangibles, Reliability, Responsiveness, Assurance and Empathy. So, $\mathrm{H}_{0}$ of Hypothesis VIII is accepted and there is no significant difference between perception and expectation of customers from urban and rural branch in terms of Tangibles, Reliability, Responsiveness, Assurance and Empathy (Appendix 8).

\section{Hypothesis 9}

The value of SERVQUAL dimensions of chi Square is 0.0197 lesser than the critical value (15.507) at $5 \%$ level of significance (d.f. $=8)$ to get difference in perception and expectation of customers from Private, Public and Public and Private banks in terms of Tangibles, Reliability, Responsiveness, Assurance and Empathy. So, $\mathrm{H}_{0}$ of Hypothesis IX is accepted and there is no significant difference between perception and expectation of customers from Public, Private, Private and Public banks in terms of Tangibles, Reliability, Responsiveness, Assurance and Empathy (Appendix 9).

\section{Discussion}

On the basis of above analysis, based upon the secondary data obtained from the Indian banking customers. It is observed that there is no significant difference in customers' satisfaction in terms of customers from rural and urban branch, income groups of the customers. The rural and urban branches are rendering equal services to their customers whatever banking services their customers are expecting. But, Puja K and Yukti A [15] reveals that Private Banks have more satisfied customers due to good services. This might be due tangibles and behavioral considerations of the employees 
of private banks. The expectations and perceptions of urban and rural customers are no different in terms of tangibles, reliability, responsiveness, assurance and empathy. The urban and rural customers are satisfied with the services of banks. There is no consideration of customers' economic condition by the banks or employees of the banks. Behavior of banks' employees in public and private sector banks are not different according to financial position of the customers. Types of bank accounts and gender of the customers are not considerable factors for discrimination in the customers from Public and Private Banks. There is no difference in private and public banks on the basis of types of accounts of customers and their gender. Customers of Public and Private Banks are satisfied but the gap between perception and expectation are more in private sector banks. So, customers of Private sector banks are more satisfied than public sector banks. There is significant difference in satisfaction in terms of their employment and jobs. This is because of the negative behavior of the banks' employees towards customers' services. The customers satisfaction level is also differ in public sector banks and private sector banks. The customers of Public sector banks are not satisfied with the interrupted services of ATMs in rural and remote areas and even they are not assured about the safety of charging service charges and courteous services of the banks' staff. The ATMs of Public sector banks are always crowded. Justin P, Arun M \& Garima S [5] explains same about Private sector banks' fast services, quick connection to the right person, efforts to reduce time in processing transactions, knowledge of the banks products and responsiveness of the employees are positively associated with the customers' satisfaction level. There is gender wise uneven banking customers in Public, Private, Public and private banks. This reveals the satisfaction differences in banking customers based on male and female. There are contradictory results about the satisfaction levels of customers in Public and Private sector Banks. Because, demographical analysis revels that there is significant difference between the satisfaction level of Private and Public Bank, But SERVQUAL dimension analysis is revealing no significant difference in satisfaction between public and private sector banks. This difference might be irrational sampling. The SERVQUAL gap between perceptions and expectations are positive in Public and Private Banks except assurance dimension of Public Banks. Puja K and Yukti A advocated that success mantra could be customer centric orientation. Overall, Customers are satisfied from Public and Private sector Banks but comparatively more from Private sector Banks [15-19].

\section{Conclusion}

In Indian banking industry, banking customers from Urban and Rural areas are satisfied and there is no significant difference among the customers from the Urban and Rural areas. But, behaviors of Public sector banks' employees are not supportive in comparison to Private sector Banks. There are some infrastructural, tangibles and ATMs related problems in Public sector Banks. There is need to provide special training to the Public Banks employees' to deal cordially with the customers of different jobs, employment and gender. ATMs of Public Banks should be established at more convenient and easy reachable places. There should be equipment of latest technology Public sector banks to avoid inconvenience and delay. Although, customers of Public and private Banks are satisfied but level of satisfaction in Private banks is higher than the Public Banks due to some tangible and behavioral consideration. In this research, there is only consideration of service quality dimensions to customers' satisfaction. So, there is further research scope available to get satisfaction level of Public and Private bank customers' weighing various aspects of loans and deposit schemes of Private and Public sector banks.

\section{References}

1. Anis A, Ratwani B. Customers' satisfaction in Indian banks: Problems and solutions. Int J Econ Res 2017;14:6976.

2. Dash A, Patra SK. Service quality and customer satisfaction: An empirical investigation on public sector banks in Odisha. J Res Mark 2014;2:113-118.

3. Gill HS, Arora S. Study of customer satisfaction: A comparison of public and private banks. Pacific Bus Rev Int 2013;6:74-79.

4. Anita. A comparative study of public and private sector banks of India in regard to customer satisfaction. Int $\mathbf{J}$ Rev Sur Res 2014;3:1-11.

5. Paul J, Mittal A, Srivastav G. Impact of service quality on customer satisfaction in private and public sector banks. Int J Ban Mark 2016;34:606-622.

6. Singh K, Gupta N. Customer's perception and satisfaction towards services of public \& private sector banks. Int $\mathrm{J}$ Manag 2016;7:77-88.

7. Bhatia K, Chouhan N, Joshi N. Comparative Study of Performance of Public and Private Sector Bank. Int J Core Eng Manag 2015;2:306-317.

8. Kumar J, Thamil SR. Performance evaluation of selected public and private banking sectors through camel model in India. Int J App Bus Econ Res 2016;14:5643-5649.

9. Doddaraju ME. A study on customer satisfaction towards public and private sector banking services. Glo J Manag Bus Stud 2013;3:287-294.

10. Malyadri P, Sirisha S. An analytical study on trends and progress of Indian banking industry. J Bus Fin Aff 2015;4:136.

11. Mishra US, Mishra BB, Praharaj S, Mahapatra R. CRM in banks: A comparative study of public and private sectors in India. Euro J Soci Sci 2011;24:265-277.

12. Mishra US, Sahoo KK, Mishra S, Patra SK. Service quality assessment in banking industry of India: A comparative study between public and private sectors. Euro J Soci Sci 2010;16:663-679. 
13. Nirmal JV, Prabhjot KM. Customer Satisfaction: A comparative analysis of public and private sector banks in India. Info Know Manag 2012;2:1-7.

14. Parasuraman A, Berry LL, Zeithaml VA. Servqual: A multiple-item scale for measuring consumer perceptions of service quality. J Ret 1988;64:12.

15. Puja K, Yukti A. Comparative study of customer satisfaction in Indian public sector and private sector banks. Int J Eng Manag Sci 2010;1:42-51.

16. Puri J, Yadav SP. Performance evaluation of public and private sector banks in India using DEA approach. Int $\mathrm{J}$
Oper Res 2013;18:91-121.

17. Seema S. Using servqual to assess the customer satisfaction level: A study of an urban cooperative bank. J Eco Pub Fin 2016;2:57-85.

18. Umma S, Mir AS. Customer satisfaction: A comparative analysis of public and private sector banks in Bangladesh. Euro J Bus Manag 2013;5:1-7.

19. Vijay PG, Agarwal PK. Comparative study of customer satisfaction in public and private sector banks in India. Glob J Bus Manag 2013;7:15-26.

\section{*Correspondence to:}

Anis Ali

CBAK, Prince Sattam bin Abdulaziz University, KSA Saudi Arabia

E-mail: ah.ali@psau.edu.sa 